\title{
ANALISIS NILAI-NILAI SOSIAL DALAM KUMPULAN CERITA RAKYAT BANGKA BELITUNG
}

\author{
Mulyati \\ Dosen Universitas Muhammadiyah Palembang \\ Jalan Jenderal Ahmad Yani, Palembang \\ Sur-el: mulyatirozie@ump.ac.id
}

\begin{abstract}
Abstrak: Latar belakang penelitian ini untuk memberikan pemahaman terhadap nilai-nilai sosial yang ada dalam kumpulan Cerita Rakyat Bangka Belitung kepada pembaca agar dijadikan rujukan dan mengenalkan kembali cerita rakyat di masa modern ini kepada pembaca. Masalah dalam penelitian ini adalah nilai-nilai sosial apa saja yang terkandung dalam kumpulan cerita rakyat Bangka Belitung? Penelitian ini bertujuan untuk mengetahui dan mendeskripsikan nilai-nilai sosial yang terkandung dalam kumpulan cerita rakyat Bangka Belitung. Metode yang digunakan dalam penelitian ini adalah metode deskriptif kualitatif. Hasil penelitian ini adalah: 1) Nilai kasih sayang yang terdiri dari: pengabdian, tolong menolong, kekeluargaan, kesetiaan, dan kepedulian. 2) Nilai tanggung jawab yang terdiri dari:rasa memiliki, disiplin, dan empati. 3) Nilai keserasian hidup yang terdiri dari: keadilan, toleransi, kerja sama, dan demokrasi.
\end{abstract}

Kata kunci: nilai sosial, cerita rakyat

\begin{abstract}
The background of this research is to provide an understanding of social values that are in the collection of the folklore of Bangka Belitung to the reader in order to be used as a reference and reintroduced the folklore in modern times is to the reader. The problem in the research is what social values contained in the collection of the folklore of Bangka Belitung? This research aims to know and describe the social values that are contained in the collection of the folklore of Bangka Belitung. The method used in this research is descriptive qualitative method. The results of this study are as follows. 1) Value of affectionate; devotion, helping each other, kinship, loyalty and caring. 2) Value of responsibility; sense of belonging, discipline, and empathy. 3) The value of the harmony of life; justice, tolerance, cooperation, and democracy.
\end{abstract}

Keywords: social values, folklore

\section{PENDAHULUAN}

Sastra merupakan cabang ilmu kesenian yang selalu berada dalam peradaban manusia dahulu. Kehadiran sastra diterima sebagai salah satu realitas sosial budaya, di tengah peradaban manusia yang tidak dapat ditolak. Sampai pada saat ini, sastra tidak saja dinilai sebagai sebuah karya seni yang memiliki budi, imajinasi, dan emosi, tetapi telah dianggap suatu karya yang kreatif dan dimanfaatkan oleh manusia. Keanekaragaman tersebut memiliki ciri khas tersendiri dan hal itu memberikan permasalahan dengan pemahaman serta tanggapan yang berbedabeda.

Menurut Faruk (2012, p. 77), karya sastra adalah objek manusiawi, fakta kemanusiaan, atau fakta kultural, sebab merupakan hasil ciptaan manusia. Menurut Endraswara (2016, p. 9), karya sastra merupakan suatu produk ciptaan seorang sastrawan, di dalamnya ada pesan ekologis yang ingin disampaikan kepada pembacanya. 
Berdasarkan pendapat di atas, dapat disimpulkan bahwa karya sastra adalah ciptaan yang disampaikan dengan komunikatif tentang maksud penulis untuk tujuan estetika.

Salah satu karya sastra adalah cerita rakyat. Menurut Sisyono, dkk (2008, p. 4), cerita rakyat adalah salah satu karya sastra yaitu berupa cerita yang lahir, hidup, dan berkembang pada beberapa generasi dalam masyarakat tradisional, baik masyarakat itu telah mengenal huruf atau belum, disebarkan secara lisan, mengandung survival, bersifat anonim, serta disebarkan secara kolektif dalam kurun waktu yang cukup lama.

Sebagai genre sastra lisan, cerita rakyat memiliki manfaat yang banyak bagi masyarakat pendukungnya. Kini, budaya lokal yang menjadi ciri khas dan jiwa bangsa semakin terkikis oleh budaya asing. Demikian halnya, cerita rakyat seakan-akan terlupakan dan tidak dikaji. Di dalam perkembangan zaman dan teknologi sekarang ini, bertambahnya pengetahuan dan berubahnya gaya hidup masyarakat berpengaruh pada sastra dunia. Banyak bermunculan sastrasastra modern dengan asas kebebasan yang sering kali mengabaikan jati diri bangsa. Cerita rakyat sebagai salah satu hiburan dalam masyarakat tampaknya tenggelam oleh cerita sinetron dan sejenisnya yang disuguhkan di televisi. Salah satu alasannya, sinetron lebih nyata alurnya sehingga mudah dipahami dan dinikmati. Padahal, cerita rakyat merupakan tradisi budaya yang memegang nilai-nilai luhur. Cerita rakyat suatu daerah merupakan salah satu warisan budaya masa lampau, masih dibutuhkan dan berguna pada masa kehidupan nyata masyarakat Indonesia saat ini, baik ditinjau dari segi sosial maupun budaya.

Salah satu cerita rakyat tersebut, yaitu dari Bangka Belitung yang merupakan jenis dari sastra lama. Sastra lama, baik yang berbentuk prosa maupun berbentuk puisi, adalah milik rakyat yang sejati sebagai bagian dari kehidupan masyarakat. Pengembangan, pewarisan, dan penyebarannya dilakukan dari mulut ke mulut secara tradisional, sehingga sastra lama umumnya berbentuk lisan.

Karya sastra juga tidak terlepas dari nilai-nilai kehidupan salah satunya adalah nilai sosial. Menurut Gabriel dalam Endraswara (2016, p. 67), nilai adalah suatu ideal, suatu paradigma yang menyatakan realitas sosial yang diingini dan dihormati.

"Sosial adalah sesuatu yang dicapai, dihasilkan dari ditetapkan dalam interaksi sehari-hari antara warga negara dan pemerintahannya". (Lewis, 2018,https://buntohacker.wordpress.com /materi pemelajaran/sosial/pengertiandan-definisi-sosial-menurut-para-ahli/.

Di dalam penelitian ini, peneliti mengkaji tentang analisis nilai sosial yang terkandung dalam buku kumpulan cerita 
rakyat Bangka Belitung karya Maulana Syamsuri.

Maulana Syamsuri adalah seorang penulis yang lahir pada 13 Maret 1943 di Perdagangan Simalungun, Sumatera Utara, Indonesia. Setelah tamat SMA tahun 1962 beliau langsung menekuni sastra, terutama novel dan cerpen yang telah dimuat di berbagai media di Kota Medan, Jakarta, Yogyakarta, Surabaya, dan Malaysia. Enam karyanya telah terbit dalam bentuk buku, (1) Seteguk Air Zam-Zam, Medan 2005. (2) Perempuan Merajut Gelombang, Yogyakarta 2006. (3) Pintu-Pintu Keampunan, Medan 2006. (4) Pernak-Pernik Puisi, Medan 2007. (5) Itshuko, Kumpulan cerpen, Medan 2010.

(6) Cerita Rakyat Bangka Belitung, Surabaya 2012. Khusus novel Perempuan Merajut Gelombang, menjadi dokumentasi di Konninklik Institut of Southest Asian and Carribien Studies (KITLV).

Berdasarkan uraian di atas, peneliti memilih karya Maulana Syamsuri, karena di dalam buku Cerita Rakyat Bangka Belitung karya beliau banyak mengandung nilai-nilai sosial yang merupakan objek dari penelitian ini.

Peneliti tertarik menganalisis cerita rakyat dari Provinsi Bangka Belitung, karena semakin lama semakin jarang ditemui atau sedikit orang yang mengetahui tentang ceritacerita rakyat Bangka Belitung, demi menjaga keaslian cerita diperlukan informasi mengenai cerita rakyat tersebut sebagai sumber. Oleh karena itu, penulis akan mendeskripsikan cerita rakyat tersebut yang di tinjau dari nilai sosial. Berdasarkan latar belakang dan uraian di atas, maka masalah penelitian ini adalah nilai-nilai sosial apa saja yang terkandung dalam kumpulan cerita rakyat Bangka Belitung?, dan tujuan penelitian ini adalah untuk mengetahui dan mendeskripsikan nilainilai sosial yang terkandung dalam kumpulan cerita rakyat Bangka Belitung.

\section{METODOLOGI PENELITIAN}

Metode yang digunakan dalam penelitian ini adalah metode deskriptif kualitatif. "Metode deskriptif kualitatif adalah metode penelitian yang bertujuan untuk menggambarkan secara utuh dan mendalam tentang realitas sosial dan berbagai fenomena yang terjadi di masyarakat yang menjadi subjek penelitian sehingga tergambarkan ciri, karakter, sifat, dan model dari fenomena tersebut." (Sanjaya, 2013, p. 47).

Pendekatan penelitian yang digunakan untuk menganalisis nilai sosial yang terdapat dalam kumpulan cerita rakyat Bangka Belitung adalah pendekatan sosiologi sastra. Menurut Ratna (2003, p. 2), ada sejumlah definisi mengenai sosiologi sastra yang perlu dipertimbangkan dalam rangka menemukan objektivitas hubungan antara karya sastra dengan masyarakat, antara lain.
a. Pemahaman terhadap karya sastra dengan pertimbangan aspek kemasyarakatannya.
b. Pemahaman terhadap totalitas karya yang disertai dengan aspek 
kemasyarakatn yang terkandung di dalamnya.

c. Pemahaman terhadap karya sastra sekaligus hubungannya dengan masyarakat yang melatarbelakangi.

d. Sosiologi sastra adalah hubungan dua arah (dialektik) antara sastra dengan masyarakat.

e. Sosiologi sastra berusaha menemukan kualitas interdepensi antara sastra dengan masyarakat.

Penelitian ini menggunakan jenis penelitian kajian pustaka. Menurut Semi (2012, p. 10), penelitian yang dilakukan dikamar kerja peneliti atau diruang perpustakaan, dimana peneliti memperoleh data dari informasi tentang objek penelitiannya lewat buku-buku atau alat-alat audiovisual lainnya.

Sumber data penelitian ini adalah buku cerita rakyat Bangka Belitung. Data penelitian ini adalah berupa teks yang terdapat pada buku kumpulan cerita rakyat Bangka Belitung karya Maulana Syamsuri yang diterbitkan oleh Pustaka Media di Surabaya tahun 2012 dengan ukuran buku $14,5 \times 20,5 \mathrm{~cm}$ dan ketebalan buku 128 halaman.

Teknik yang digunakan untuk mengumpulkan data dalam penelitian ini berupa dengan membaca teks tertulis buku cerita rakyat Bangka Belitung. Selanjutnya, teks tersebut dianalisis dengan menggunakan teknik analisis karya yang ditinjau dari nilai sosial.

Teknik analisis ini bertujuan untuk menentukan dan mendeskripsikan kepribadian dari para tokoh dengan kehidupan yang di dalamnya terkandung nilai-nilai sosial yang memengaruhinya. Untuk menganalisis dengan teknik analisis karya melalui metode deskriptif kualitatif, Peneliti merujuk pada rumusan (Sugiyono, 2015, p. 338-345), sebagai berikut.

1. Reduksi data, yaitu merangkum, memilih hal-hal yang pokok, memfokuskan pada hal-hal yang penting.

a. Membaca teks tertulis buku kumpulan cerita rakyat Bangka Belitung.

b. Mencari nilai-nilai sosial yang terkandung dalam kumpulan cerita rakyat Bangka Belitung.

2. Penyajian data, yaitu menyajikan data secara tersusun dalam pola hubungan dalam bentuk uraian singkat, sehingga mudah dipahami.

a. Menyajikan hasil dari analisis, yaitu nilai-nilai sosial yang terkandung dalam kumpulan cerita rakyat Bangka Belitung dalam bentuk uraian singkat.

3. Penarikan kesimpulan, yaitu temuantemuan yang dapat berupa deskripsi atau gambaran suatu objek.

a. Mendeskripsikan nilai-nilai sosial yang terkandung dalam kumpulan cerita rakyat Bangka Belitung secara tersusun. 


\section{HASIL}

\section{A. Nilai Kasih Sayang}

Nilai kasih sayang terdiri atas pengabdian, tolong-menolong, kekeluargaan, kesetiaan, dan kepedulian.

\section{1) Pengabdian}

Nilai pengabdian dalam kumpulan Cerita Rakyat Bangka Belitung dapat dilihat dalam kutipan berikut:

\section{"Setelah bertahun-tahun menimba ilmu kesaktian dari seorang guru, kini ia kembali kepada keluarganya. Penduduk menyam-but gembira kedatangan Bujang Anom, karena dialah tumpuhan harapan mereka untuk terlepas dari penindasan" (Riwayat Batu Meja, 2012, p. 39).}

Dalam kutipan di atas, menjelaskan tentang seorang lelaki yang ingin mengabdi di desanya untuk menyelamatkan dari penindasan. Isi dari kutipan di atas, merupakan seorang pemuda yang ingin mengabdi menyelamatkan desanya dari penindasan.

"Sejak saat itu mereka menerima si Kelingking sebagai anggota keluarga dan tidak lagi berusaha membunuh. Dengan hadir-nya anak itu, maka pekerjaan sang ayah men-jadi lebih ringan dan ke-butuhan hidup mereka dapat terpenuhi" (Kisah Si Kelingking, 2012, p. 28).

Dalam kutipan di atas, menjelaskan tentang pengabdian seorang anak yaitu si Kelingking kepada orang tuanya, walaupun ia sudah sering ingin dibunuh oleh kedua orang tuanya. Isi dari kutipan di atas, merupakan pengabdian seorang anak kepada kedua orang tuanya.
"Di hari yang lain Dayang Samak mengajak seluruh warga untuk bergotong royong memajukan desa, memperbaiki jalan dan rumah yang sudah tua" (Kisah Putri Nurjanu, 2012, p. 57).

Dalam kutipan di atas, menjelaskan tentang seorang pemimpin desa yaitu Dayang Samak yang ingin membuat desanya lebih maju. Isi dari kutipan di atas, merupakan pengabdian seorang pemimpin yang ingin membuat desanya maju.

\section{2) Tolong Menolong}

Nilai tolong menolong dalam kumpulan Cerita Rakyat Bangka Belitung dapat dilihat dalam kutipan berikut:

"Wahai anak muda, janganlah terkejut jika aku mendatangkanmu kemari. Karena aku sangat meng-harapkan bantuan tenagamu demi keamanan desa kita. Apa yang bisa aku bantu Tuan?. tanya pemuda itu" (Si Penyumpit dan Seorang Putri, 2012, p. 13).

Dalam kutipan di atas, menjelaskan tentang seseorang yang ingin meminta bantuan kepada seorang pemuda. Isi dari kutipan di atas, merupakan salah satu sikap tolong menolong.

"Si Penyumpit segera datang menemui Sesepuh Desa yang dalam keadaan sekarat tak sadarkan diri. Kemudian memetik bebe-rapa lembar daun uang tumbuh di belakang rumah. Daun-daun itu ditumbuk halus, kemudian diperas diambil airnya dan dimi-numkan kepada yang sakit" (Si Penyumpit dan Seorang Putri, 2012, p. 19).

Dalam kutipan di atas, menjelaskan tentang seorang pemuda yaitu si Penyumpit yang menolong Sesepuh Desa menyembuhkan penyakitnya. Isi dari kutipan di atas, 
merupakan wujud saling tolong menolong atau sikap peduli antara masyarakat.

"Sebagai seorang gadis yang berjiwa besar, Putri Pinang Gading menerima baik kedatangan mereka. Bahkan ia menyanggupi permintaan orang-orang itu " (Asal Mula Keramat Pinang Gading, 2012, p. 35).

Dalam kutipan di atas, menjelaskan tentang seorang Putri yang bernama Pinang Gading yang bersedia menolong penduduk desa. Isi dari kutipan di atas merupakan wujud tolong menolong.

\section{3) Kekeluargaan}

Nilai kekeluargaan dalam kumpulan Cerita Rakyat Bangka Belitung dapat dilihat dalam kutipan berikut:

"Sang ibu segera duduk di sisi putrinya dengan menampakkan rasa kasih sayang, kemudian bertanya "Anakku, berkatalah terus terang. Kenapa selama ini engkau selalu menolak se-tiap ada lamaran yang datang"(Asal Mula Pulau Belitung, 2012, p. 6).

Dalam kutipan di atas, menjelaskan tentang perhatian seorang ibu kepada anaknya. Isi dari kutipan di atas, merupakan wujud kekeluargaan.

"Karena tidak dapat me-nahan haus, si Manis pulang ke rumah sambil menangis. Tuk Pancor sangat terkejut melihat anaknya menangis, ke-mudian bertanya: Kenapa menangis nak, apakah engkau sedang tidak enak badan?" (Kisah Telaga Muyang Manis, 2012, p. 47).

Dalam kutipan di atas, menjelaskan tentang perhatian seorang ayah kepada anaknya yang sedang menangis. Isi kutipan di atas, merupakan sebuah wujud kekeluargaan.
"Namun betapa terkejutnya setelah Mak Dambek tiba di sana. Anaknya tidak berada di tempat, sedang-kan susunan batu yang me-magari telah berserakan. Perempuan itu jadi panik, ia mencarinya ke sana ke mari tanpa mengenal lelah" (Asal Mula Padang Buang Anak, 2012, p. 53).

Dalam kutipan di atas, menjelaskan tentang perjuangan seorang ibu yang tanpa lelah mencari anaknya yang hilang. Isi kutipan di atas, merupakan wujud kekeluargaan antara seorang ibu dan anak.

\section{4) Kesetiaan}

Nilai kesetiaan dalam kumpulan Cerita Rakyat Bangka Belitung, dapat dilihat dalam kutipan berikut:

"Pada jaman dahulu di sebuah desa di Pulau Belitung terdapat sepasang suamiistri yang hidup da-lam kemiskinan. Namun demikian mereka dapat menerima keadaan, se-hingga terciptalah suasana yang bahagia" (Kisah Si Kelingking, 2012, p. 22).

Dalam kutipan di atas, menjelaskan tentang kesetiaan sepasang suami-istri yang hidup bahagia walaupun miskin. Isi kutipan di atas, merupakan salah satu wujud kesetiaan.

"Cukup lama mereka menikah, namun belum juga mempunyai keturunan. Meskipun demikian tidak mengurangi kasih sayang di antara keduanya. Kemana saja mereka pergi selalu berdua, sehingga susah dan senang dapat dirasakan bersama" (Asal Mula Keramat Pinang Gading, 2012, p. 30).

Dalam kutipan di atas, menjelaskan tentang kesetiaan sepasang suami istri yang hidup bahagia walaupun tidak mempunyai keturunan. Isi kutipan di atas, merupakan wujud kesetiaan. 
"Bujang Dultalip tersentak kaget, ia menangis keras seraya memanggilmanggil namanya: Nurjanu...Nurjanu...jangan tinggalkan aku...Sungguh aku sangat mencintaimu" (Kisah Telaga Muyang Manis, 2012, p. 59).

Dalam kutipan di atas, menjelaskan tentang kesetiaan seorang kekasih yang ditinggal mati. Isi kutipan di atas, merupakan wujud kesetiaan.

\section{5) Kepedulian}

Nilai kepedulian dalam kumpulan Cerita Rakyat Bangka Belitung, dapat dilihat dalam kutipan berikut:

"Penyakit apa yang engkau derita dan kenapa diam saja tidak memberitahu? Tanya Ibu Suri terkejut" (Asal Mula Pulau Belitung, 2012, p. 6).

Dalam kutipan di atas, menjelaskan tentang sikap kepedulian seorang ibu terhadap anaknya. Isi kutipan di atas, merupakan salah satu wujud kepedulian.

"Pemuda : Baiklah Tuan, sebagai anak satu-satunya, aku memang mempunyai kewajiban membantu orang tua. Sesepuh : Bagus, itu tan-danya anak yang ber-bakti" ( $\mathrm{Si}$ Penyumpit dan Seorang Putri, 2012, p. 13).

Dalam kutipan di atas, menjelaskan tentang kepedulian seorang anak yang ingin membantu orang tuanya.

"Sebagai seorang gadis yang berjiwa besar, Putri Pinang Gading menerima baik kedatangan mereka. Bahkan ia menyanggupi permintaan orang-orang itu "(Asal Mula Keramat Pinang Gading, 2012:35).

Dalam kutipan di atas, menjelaskan tentang kepdulian seorang gadis terhadap musibah yang menimpa di desa tetangganya dan ingin membantu.

\section{B. Nilai Tanggung Jawab}

Nilai tanggung jawab terdiri atas nilai rasa memiliki, disiplin, dan empati.

\section{1) Rasa Memiliki}

Nilai rasa memiliki dalam kumpulan Cerita Rakyat Bangka Belitung, dapat dilihat dalam kutipan berikut:

"Sudahlah istriku, kita terima apa adanya. Sekalipun bayi ini sebesar kelingking, tetapi tetap bagian dari jiwa kita” (Kisah Si Kelingking, 2012, p. 23).

Dalam kutipan di atas, menjelaskan tentang rasa memiliki orang tua terhadap anaknya walaupun anaknya cacat.

"Tidak tahu, tetapi kurasa bayi ini bukan anak manusia biasa karena tidak ada bekas darah sedikitpun. Ah, itu tidak penting. Rawat saja bayi ini dan anggaplah sebagai anak kita" (Asal Mula Keramat Pinang Gading, 2012, p. 32).

Dalam kutipan di atas, menjelaskan tentang rasa memiliki kedua suami istri yang terhadap seorang bayi.

"Penduduk setempat sangat gembira dan merasa bangga mem-punyai seorang pemimpin muda yang tegas dan sakti. Mereka sangat ber-terima kasih dan mengelu-elukan pemuda itu" (Riwayat Batu Meja, 2012, p. 43).

Dalam kutipan di atas, menjelaskan tentang rasa memiliki para penduduk terhadap pemimpinnya. 


\section{2) Disiplin}

Nilai disiplin dalam kum-pulan Cerita Rakyat Bangka Belitung, dapat dilihat dalam kutipan berikut:

"Sedari kecil sang ayah mendidik dua keahlian itu, agar setelah dewasa menjadi orang yang ber-guna" ( $\mathrm{Si}$ Penyumpit dan Seorang Putri, 2012, p. 12).

Dalam kutipan di atas, menjelaskan tentang kedisiplinan, mengajarkan sesutau sedari kecil kepada anaknya.

"Mula-mula yang dicongkel batu-batu kecil, kemudian yang agak besar. Si Kelingking mengumpulkan batu-batu tersebut dengan cekatan. Kumpulkan batu-batu itu dengan rapi! seru lelaki itu. Ya ayah! sahut anaknya" (Kisah Si Kelingking, 2012, p. 27).

Dalam kutipan di atas, menjelaskan tentang sikap disiplin Si Kelingking yang mematuhi perintah ayahnya.

"Ki Inda membuatkannya panah dari bambu, sehingga setiap hari gadis itu dapat berlatih membidik. Lama kelamaan menjadi mahir dalam menggunakan panah dan bidikannyapun jarang sekali meleset" (Asal Mula Keramat Pinang Gading, 2012, p. 33).

Dalam kutipan di atas, men-jelaskan tentang kedisiplinan Putri Pinang Gading yang setiap hari ber-latih panah hingga mahir.

\section{3) Empati}

Nilai empati dalam kumpulan Cerita Rakyat Bangka Belitung, dapat dilihat dalam kutipan berikut:

"Pertanyaan itu membua sang Putri semakin sedih, air matanya berlinang membasahi pipi. Sang ibu memeluk putri kesayangannya. Dengan terisak- isak, gadis cantik itu mengaku bahwa dirinya menderita penyakit kelamin" (Asal Mula Pulau Belitung, 2012, p. 6).

Dalam kutipan di atas, menjelaskan tentang sikap empati yang ditunjukan oleh seorang ibu terhadap anaknya yang sedang sakit.

"Aku akan mencabut anak sumpit itu dan seka-ligus mengobati luka di tubuh putrimu. Tetapi tolong carikan aku beberapa helai daun yang tumbuh di depan gua dan tumbuklah hingga halus" ( $\mathrm{Si}$ Penyumpit dan Seorang Putri, 2012, p. 16).

Dalam kutipan di atas, menjelaskan tentang sikap empati seorang pemuda yang ingin membantu menyembuhkan seorang Putri yang sedang sakit.

"Sesampainya di rumah, Si Penyumpit tergeletak tak sadarkan diri. Istri dan anak-anaknya sangat terkejut, mereka bertangisan melihat keadaan sang ayah" (Si Penyumpit dan Seorang Putri, 2012, p. 18).

Dalam kutipan di atas, menjelaskan tentang sikap empati seorang istri dan anak-anak dari Si Penyumpit yang melihat ia tergeletak tak berdaya.

\section{Nilai Keserasian Hidup}

Nilai keserasian hidup terd iri atas nilai keadilan, toleransi, kerja sama, dan demokratis.

\section{1) Keadilan}

Nilai keadilan dalam kumpulan Cerita Rakyat Bangka Belitung, dapat dilihat dalam kutipan berikut:

"Pada jaman dahulu di Pulau Bali hiduplah se-orang raja yang memerintah dengan adil dan bijaksana. Seluruh rakyat negeri sangat 
menyayanginya" (Asal Mula Pulau Belitung, 2012, p. 5).

Dalam kutipan di atas, menjelaskan tentang seorang raja yang memerintah kerajaannya dengan adil dan bijaksana.

"Pada suatu pagi di musim panen, setelah sarapan Ki Inda berkata: Istriku, untuk kali ini kita berbagi pekerjaan. Engkau tinggal di rumah untuk menjemur padi dan aku akan pergi ke laut. Barangkali bubu yang kupasang kemarin sore telah penuh dengan ikan" (Asal Mula Keramat Pinang Gading, 2012, p. 30).

Dalam kutipan di atas, menjelaskan tentang sikap adil seorang suami dalam membagi tugas untuk isrinya.

"Anak siapa menurutmu suamiku? Tanya perem-puan itu penasaran. Tidak tahu, tetapi kurasa bayi ini bukan anak manusia biasa karena tidak ada bekas darah sedikitpun. Ah, itu tidak penting. Rawat saja bayi ini dan anggaplah sebagai anak kita, sahut lelaki itu. Benar Ki, karena kita tidak mem-punyai anak, maka bayi ini sebagai gantinya, ujar sang istri" (Asal Mula Keramat Pinang Gading, 2012, p. 32-33).

Dalam kutipan di atas, menjelaskan tentang keadilan Tuhan terhadap umatnya, Ki Inda dan Ni Inda yang telah lama menikah tetapi tidak mempunyai anak, maka di karuniainya seorang anak yang berasal dari sepotong bambu.

\section{2) Toleransi}

Nilai toleransi dalam kumpulan Cerita Rakyat Bangka Belitung, dapat dilihat dalam kutipan berikut:

"Dahulu, semasa Ayahmu masih hidup pernah ber-hutang kepadaku dan belum terlunasi sampai dia meninggal dunia. Aku pun tidak mengharap kembalinya hutang itu, tetapi aku hanya ingin bantuan tenagamu saja" (Si Penyumpit dan Seorang Putri, 2012, p. 13).

Dalam kutipan di atas, menjelaskan tentang sikap toleransi sesepuh terhadap hutang yang belum terlunasi oleh ayah Si Penyumpit.

"Sudahlah istriku, kita terima apa adanya. Sekalipun bayi ini sebesar kelingking, tetapi tetap bagian dari jiwa kita” (Kisah Si Kelingking, 2012, p. 23).

Dalam kutipan di atas, menjelaskan tentang sikap toleransi sepasang sumai istri terhadap bayi yang terlahir sebesar kelingking dan mereka mau menerimanya.

"Sang Suami berkata : Kita benar-benar tidak tahu diri. Si Kelingking ter-lahir dengan ke-adaan seperti itu adalah karena permintaan kita sendiri, maka sungguh tidak pantas jika selalu merasa terbebani. Benar suamiku, marilah kita terima dengan segala kekurangan dan kelebihannya, sahut istrinya" (Kisah $\mathrm{Si}$ Kelingking, 2012, p. 28).

Dalam kutipan di atas, menjelaskan tentang sikap toleransi sepasang suami istri terhadap anak mereka yang terlahir dengan keadaan yang tidak seperti anak lainnya.

\section{3) Kerja Sama}

Nilai kerja sama dalam kumpulan Cerita Rakyat Bangka Belitung, dapat dilihat dalam kutipan berikut:

"Datu Malim Angin segera mengayuh sampannya untuk mengejar pulau tersebut. Usaha mereka berhasil, selanjutnya Datu Malim naik ke daratan dengan membawa tampar yang panjang dan kuat" (Asal Mula Pulau Belitung, 2012, p. 10).

Dalam kutipan di atas, menjelaskan tentang kerja sama antara Datu Malim Angin dan 
Datu Langgar Tuban yang ingin mengejar pulau yang hanyut.

"Setelah anaknya menganggukkan kepala, sang ayah segera mendaki gunung dengan membawa sebatang besi. Mula-mula yang dicongkel batubatu kecil, kemudian yang agak besar. Si Kelingking me-ngumpulkan batubatu tersebut dengan cekatan" (Kisah Si Kelingking, 2012, p. 27).

Dalam kutipan di atas, menjelaskan tentang kerja sama antara ayah dan anaknya saat mengambil batu di gunung.

"Tiga hari kemudian Putri Pinang Gading datang ke desa Remban dengan membawa panah-panahnya. Penduduk setempat me-nyambut kedatangan gadis itu dengan gembira dan penuh harap. Sang Putri meminta agar ada salah seorang penduduk yang bersedia dijadikan umpan. Dalam hal ini seorang lelaki yang usianya lebih dari setengah abad bersedia memenuhi per-mintaan gadis itu" (Asal Mula Keramat Pinang Gading, 2012, p. 35-36).

Dalam kutipan di atas, menjelaskan tentang seorang putri meminta agar ada salah seorang penduduk yang ingin bekerja sama untuk membunuh burung raksasa.

\section{4) Demokrasi}

Nilai demokrasi dalam kumpulan Cerita Rakyat Bangka Belitung, dapat dilihat dalam kutipan berikut:

"Pada suatu malam yang sepi. Tatkala seisi istana pada tidur, sang raja bermusyawarah dengan permaisuri tentang putrinya. Baginda berkata : Aku benar-benar tidak mengerti, kenapa anak kita bersikap seperti itu terhadap lakilaki" (Asal Mula Pulau Belitung, 2012, p. 5).

Dalam kutipan di atas, menjelaskan tentang sikap demokrasi seorang raja dan permaisurinya dalam memecahkan masalah yang dialaminya.

"Akibatnya setiap hari suami-istri itu selalu dilanda kebingungan, karena penghasilan yang diperoleh hanya cukup untuk dimakan Si Keling-king. Karena merasa tidak mampu menghidupi anaknya, maka secara diam-diam mereka bermusyawarah" (Kisah Si Kelingking, 2012, p. 24).

Dalam kutipan di atas, menjelaskan tentang sepasang suami-istri yang bermusyawarah untuk memecahkan masalah yang melanda mereka.

"Sejumlah sesepuh desa berkumpul di suatu tempat, mereka bermusyawarah mencari cara yang tepat untuk membinasakan burung rakasasa itu" (Asal Mula Keramat Pinang Gading, 2012, p. 34).

Dalam kutipan di atas, menjelaskan tentang para sesepuh desa yang bermusyawarah untuk mencari cara membinasakan burung raksasa.

Berdasarkan dari hasil analisis penulis pada buku kumpulan Cerita Rakyat Bangka Belitung karya Maulana Syamsuri. Penulis memberikan pengetahuan kepada pembaca, pengetahuan tentang nilai-nilai kehidupan, yaitu nilai-nilai sosial. Dari kumpulan cerita rakyat Bangka Belitung terdapat 13 cerita. Dari semua cerita tersebut masing-masing mengandung nilai-nilai sosial, yaitu nilai kasih sayang yang terdiri dari pengabdian, tolong menolong, kekeluargaan, kesetiaan, dan kepedulian. Nilai tanggung Jawab yang terdiri dari rasa memiliki, disiplin, dan empati. Sedangkan nilai keserasian hidup terdiri dari keadilan, toleransi, kerja sama, dan demokratis. 
Dalam cerita Asal Mula Pulau Belitung terdapat sikap keadilan seperti yang ditunjukkan oleh sang Raja pada kerajaan di Pulau Bali yang memerintah dengan adil dan bijaksana, dalam cerita Si Penyumpit dan Seorang Putri terdapat sikap empati seperti yang ditunjukkan oleh istri dan anak-anak si Penyumpit di saat si Penyumpit tergeletak tak sadarkan diri istri dan anak-anaknya sangat terkejut, mereka bertangisan melihat keadaan sang ayah, dalam cerita Kisah Si Kelingking terdapat sikap kesetiaan seperti yang ditunjukkan oleh sepasang suami-istri yang hidup dalam kemiskinan, namun demikian mereka dapat menerima keadaan sehingga tercipatalah suasana yang bahagia, dalam cerita Asal Mula Keramat Pinang Gading terdapat sikap disiplin seperti yang ditunjukkan oleh Putri Pinang Gading yang setiap hari berlatih membidik sehingga ia menjadi mahir dalam menggunakan panah, dalam cerita Riwayat Batu Meja terdapat sikap kerja sama seperti yang ditunjukkan oleh Bujang Anom yang ingin mengajak warga desa untuk bekerja sama mengalahkan bajak laut, dalam cerita Kisah Telaga Muyang Manis terdapat sikap disiplin seperti yang ditunjukkan oleh Tuk Pancor yang tekun dalam bertanam sayuran hingga tumbuh subur, dalam cerita Asal Mula Padang Buang Anak terdapat sikap tolong menolong seperti yang ditunjukkan oleh para penduduk yang berdatangan menolong seorang kakek tua yang tampak pucat dan tidak berdaya, dalam cerita Kisah Putri Nurjanu terdapat sikap pengabdian seperti yang ditunjukkan oleh Dayang Samak selaku orang yang disegani di desa ia mengajak seluruh warga untuk bergotong royong memperbaiki jalan dan rumah yang sudah tua, dalam cerita Kisah Putri Sri Pingai terdapat sikap kepedulian seperti yang ditunjukkan oleh Ni Pancor di saat mencari arah suara bayi tanpa memperdulikan lebatnya hujan, dalam cerita Kisah Raja Berekor terdapat sikap kekeluargaan seperti yang ditunjukkan oleh sang Putri yang menghidupi anaknya seorang diri dengan memberi makan buah-buahan yang tumbuh di hutan dan minum air sungai, dalam cerita Kisah Si Bujang Katak terdapat sikap keadilan seperti yang ditunjukkan oleh sang Raja yang bertindak adil tentang orang yang ingin melamar putrinya tidak ada keharusan dari bangsawan atau putra raja, dalam cerita Panglima Angin terdapat sikap pengabdian seperti yang ditunjukkan oleh Abang Daud yang ingin menjadi murid Pek Long, dan di dalam cerita Keramat Bujang terdapat sikap pengabdian seperti yang ditunjukkan oleh Bujang yang sangat menghormati Tuk Rangga walaupun ia tahu kalau sebenarnya ia adalah anak angkat.

Sedangkan teori yang dijelaskan oleh Zubaedi (2012, p. 13) mengatakan bahwa, nilai-nilai sosial terdiri dari beberapa subnilai, diantaranya: 1) Nilai kasih sayang yang terdiri dari pengabdian, tolong menolong, kekeluargaan, dan kepedulian. 2) Nilai tanggung jawab yang terdiri dari rasa memiliki, disiplin, dan empati. 3) Nilai keserasian hidup yang terdiri dari keadilan, toleransi, kerja sama, dan demokrasi.

Dari hasil penelitian yang telah dilakukan penulis dalam buku Cerita Rakyat Analisis Nilai-Nilai Sosial Dalam Kumpulan Cerita Rakyat Bangka Belitung (Mulyati) 
Bangka Belitung karya Maulana Syamsuri, ditemukan semua nilai-nilai sosial sesuai dengan teori yang disampaikan oleh Zubaedi, yaitu meliputi: 1) Nilai kasih sayang yang tediri dari pengabdian, tolong menolong, kekeluargaan, kesetiaan, dan kepedulian. 2) Nilai tanggung jawab yang terdiri dari rasa memilki, disiplin, dan empati. 3) Nilai keserasian hidup terdiri dari keadilan, toleransi, kerja sama, dan demokrasi.

\section{Simpulan}

Berdasarkan dari hasil analisis dan pembahasan pada buku Cerita Rakyat Bangka Belitung karya Maulana Syamsuri, penulis menyimpulkan bahwa dalam 13 cerita rakyat tersebut terdapat nilai-nilai sosial yang terdiri dari: 1) Nilai kasih sayang adalah rasa yang tulus dalam hati dan mengandung sebuah keinginan untuk mencintai, memberi, menyayangi, dan membahagiakan. Kasih sayang dapat diberikan kepada siapa saja yang dikasihi seperti orang tua, sahabat, dan lain-lain. 1) Nilai kasih sayang terdiri dari a) pengabdian, b) tolong menolong, c) kekeluargaan, d) kesetiaan, dan e) kepedulian. 2) Nilai Tanggung jawab adalah kesadaran manusia akan tingkah laku atau perbuatan yang sengaja dilakukan. Tanggung jawab dapat diartikan juga sebagai perbuatan seseorang akan perwujudan kesadaran terhadap kewajibannya. Nilai tanggung jawab terdiri dari a) rasa memiliki, b) disiplin, dan c) empati. 3) Nilai keserasian hidup adalah manusia sebagai makhluk sosial karena selalu berinteraksi dengan manusia lainnya dalam melakukan aktivitas kehidupan sehari-hari, dalam kehidupan bersosial tersebut harus ada norma-norma yang disepakati bersama agar kehidupan berjalan serasi, seimbang, dan harmonis. Nilai keserasian hidup terdiri dari a) keadilan, b) toleransi, c) kerja sama, dan d) demokrasi. 


\section{DAFTAR RUJUKAN}

Endraswara, Suwardi. 2016. Sastra Ekologis Teori dan Praktik Pengkajian. Yogyakarta: CAPS (Center for Academic Publishing Service).

Faruk. 2012. Metode Penelitian Sastra. Yogyakarta: Pustaka Pelajar.

Manchester United Will Never Die. Pengertian Sosial Menurut Para Ahli. (Online). (Diakses dari https://buntohacker.wordpress.com $/ m$ ateri-pemelajaran/sosial/pengertiandan-definisi-sosial-menurut-paraahli/, 4 Agustus 2018).

Maulana, Syamsuri. 2012. Kumpulan Cerita Rakyat Bangka Belitung. Surabaya: Pustaka Media.

Ratna, Nyoman Khuta. 2003. Paradigma Sosiologi Sastra. Yogyakarta: Pustaka Pelajar.
Sanjaya, Wina. 2013. Penelitian Pendidikan Jenis, Metode, dan Prosedural. Jakarta: Prenada Media Group.

Semi, M. Atar. 2012. Metode Penelitian Sastra. Bandung: CV Angkasa.

Sisyono, Eko Widodo. 2008. Foklor Jawa di Daerah Aliran Sungai Bengawan Solo dan Sumbangannya Terhadap Pelestarian Lingkungan. Jakarta: Perpustakaan Nasional RI.

Sugiyono. 2015. Metode Penelitian Pendidikan (Pendekatan Kuantitatif, Kualitatif, dan R\&D). Jakarta: CV Alfabeta.

Zubaedi. 2012. Pendidikan Berbasis Masyarakat. Yogyakarta: Pustaka Pelajar. 